\section{OP0037 FIBRINOLYTIC SYSTEM AND ACE I/D POLYMORPHISM IN SYSTEMIC SCLEROSIS}

${ }^{1} \mathrm{C}$ Angotti, ${ }^{2} \mathrm{~F}$ Gensini, ${ }^{2} \mathrm{C}$ Fatini, ${ }^{3} \mathrm{~B}$ Battaglini, ${ }^{3} \mathrm{E}$ Sticchi, ${ }^{4} \mathrm{~S}$ Fedi, ${ }^{1} \mathrm{~A}$ Righi, ${ }^{5} \mathrm{G}$ Pepe, ${ }^{4} \mathrm{R}$ Abbate, ${ }^{1} \mathrm{M}$ Matucci Cerinic. 'Department Internal Medicine, Section of Rheumatology; ${ }^{2}$ Department Clinical Physiopathology, Sect of Gen; ${ }^{3}$ Department Medicine and Surgery; ${ }^{4}$ Thromb Cent, University of Florence, Florence; ${ }^{5}$ Deptarment Internal Medicine, University Tor Vergata, Rome, Italy

\subsection{6/annrheumdis-2001.294}

Background In Systemic sclerosis (SSc), an imbalance of the fibrinolytic system was shown. In vivo and in vitro studies suggest a role for Renin Angiotensin System in the regulation of fibrinolytic balance: Angiotensin II (Ang II) increases the plasminogen activator inhibitor? 1 (PAI-1) production and secretion, and ACE reduces $\mathrm{t}-\mathrm{PA}$ production. A polymorphism in the ACE gene consisting of an insertion or deletion (I/D) of $287 \mathrm{bp}$ fragment in intron 16 was described. The D allele of ID polymorphism is associated with an increased level of ACE and ACE gene polymorphism may influence the production of Ang II.

Objectives To investigate possible alterations in the fibrinolytic system and to examine the role of ACE I/D polymorphism in SSc.

Methods PAI-1 activity, t-PA and D-Dimer plasma levels were measured in 61 SSc patients (36 limited, 25 diffuse) and 108 healthy controls. ACE I/D polymorphism was genotyped by PCR. PAI-1 activity and t-PA levels were assayed by chromogenic method and D-Dimer levels by ELISA.

Results A significant difference in ACE genotype distribution (chi2 $=9.79 \mathrm{p}=0.007)$ and allele frequency was observed between patients and controls $(0.64$ vs $0.50 \mathrm{p}=0.009)$. In limited SSc a higher frequency of ACE D allele was found (0.68 vs 0.56 in diffuse SSc $\mathrm{p}=0.23$ ). By univariate analysis an association between ACE D allele and limited, but not diffuse SSc, was found $(\mathrm{OR} \mathrm{DD}+\mathrm{ID} / \mathrm{II}=6.4495 \%$ CI $1.45-28.54 \mathrm{p}=0.005$ and OR DD+ID/II $=1.9195 \%$ CI $0.60-6.08 \mathrm{p}=0.31$ respectively). Median values of PAI-1, t-PA and D-Dimer were $6.2 \mathrm{U} /$ $\mathrm{ml}$ (range 1-37.5),10.5 ng/mL (range 4.3-28.1) and $156 \mathrm{ng} / \mathrm{mL}$ (range 64-1064, respectively. Patients had higher t-PA and DDimer mean levels than controls $(p=0.000001$ and $p=0.02$, respectively). No difference was observed in PAI-1 plasma levels between patients and controls $(\mathrm{p}=0.85)$. No association between high PAI-1, t-PA and D-Dimer plasma levels and ACE $\mathrm{D}$ allele was observed.

Conclusion These data suggest that ACE D allele is highly associated with limited SSc. Thus, we could hypothesise that this allele may represent a risk factor for the development of limited SSc. Other mechanisms than the alterations of fibrinolytic system may have a role in determining the microvascular damage.

\section{OP0038 AUTOLOGOUS HEMATOPOIETIC STEM CELLS (HSC) TRANSPLANTATION IN SCLERODERMA AND MYOSITIS}

DC Farge, S Zohar, MH Andre, J Cabane, E Hachulla, P Philippe, J Sibilia, P Roblot, J Piette, S Chevret, JP Marroleau, E Gluckman. Internal Medicine, Saint Louis, Paris, France

\subsection{6/annrheumdis-2001.295}

Background Autologous bone marrow transplant is a new treatment for autoimmune diseases (AD).

Objectives To determine the feasibility, tolerance and efficacy of autologous HSC transplantation with $\mathrm{CD} 34^{+}$selection in severe scleroderma $(\mathrm{Sc})$ and myositis $(\mathrm{M})$.
Methods We designed a national, non randomised, open, phase I-II trial. ${ }^{1}$ Mobilisation of HSC used cyclophosphamide (CYCLO) $\left(4 \mathrm{~g} / \mathrm{m}^{2}\right)+\mathrm{G}-\mathrm{CSF}$ (5 microg/kg day) or G-CSF alone (10 microg/ $\mathrm{kg}$ day) if left ventricular ejection fraction (LVEF) was $<40 \%$ until last apheresis. $9.5 \times 106 \mathrm{CD}^{+} 4^{+} / \mathrm{kg}$ had to be collected in successive daily apheresis to obtain at least $2.5 \times 106 \mathrm{CD}^{2} 4^{+} / \mathrm{kg}$ (Isolex $300 \mathrm{i})$. Conditioning used CYCLO $(200 \mathrm{mg} / \mathrm{kg})$, or melphalan $\left(140 \mathrm{mg} / \mathrm{m}^{2}\right)$ if LVEF was $<40 \%$, prior to CD34 ${ }^{+} \mathrm{HSC}$ reinfusion. Patients, haematological and immunological reconstitutions were recorded up to the end of aplasia and every 3 months thereafter. Sequential Bayesian analysis determined the rate of failure (either death or failure of mobilisation, selection or intensification) and results (median) were computed on a SAS program (6.0).

Results $12 \mathrm{Sc}+3 \mathrm{M}$, age 36 yrs, were included in 2 years, meanwhile 10 candidates died from their disease. HSC mobilisation was successful in 14 patients, but in 2 cases did not yield enough HSC to allow CD34 $4^{+}$selection. After $2(1-4)$ aphereses, the total number of $\mathrm{CD} 34^{+}$collected for each patient was 10.9 $\times 106 / \mathrm{kg}$ (3.9?34.3). Purity was 99.2\% (92-99.8). CD34 ${ }^{+}$cells yield was $60.7 \%$ (46.4-80). Intensive immunosuppression was performed in 13 patients with low toxicity. Number of reinfused cells was $5.8 \times 106 \mathrm{CD} 34^{+} / \mathrm{kg}(3.3-10.2)$. Duration of aplasia was 2.9 weeks $(2.5-3)$ with low toxicity. No mortality was associated with the procedure. Early clinical evolution (18 mths) showed improved functional status (PS, SHAQ) and fall in skin score in $8 / 12 \mathrm{Sc}$ and no clinical benefit in $\mathrm{M}$.

Conclusion Autologous HSC transplantation is feasible in Sc and $\mathrm{M}$, with a lower risk compared to spontaneous evolution of $\mathrm{AD}$ and early clinical benefit in Sc. These results call for phase III studies to compare cyclophosphamide alone versus autologous transplantation in Sc and for more myositis in phase I-II studies.

\section{REFERENCE}

1 Farge D, Gluckman E, Tyndall A. Treatment of severe autoimmune diseases by immunoablative chemotherapy and autologous bone marrow transplantation. EJIM 1999;10:88-96

\section{OP0039 EVIDENCE OF THE INTRACELLULAR CYTOKINES IN PERIPHERAL BLOOD MONONUCLEAR CELLS OF PATIENTS WITH SYSTEMIC SCLEROSIS}

${ }^{1} \mathrm{C}$ Naclerio, ${ }^{2} \mathrm{~K}$ Esposito, ${ }^{2} \mathrm{~A}$ Farzati, ${ }^{1} \mathrm{G}$ Cuomo, ${ }^{1} \mathrm{G}$ Valentini, ${ }^{2} \mathrm{~B}$ Farzati. ${ }^{1}$ Rheumatology Unit, ${ }^{2}$ Immunohematology Unit, Second University of Naples, Naples, Italy

\subsection{6/annrheumdis-2001.296}

Background Systemic sclerosis (SSc) is currently considered aTh2 disease. The studies underlying such assumption have been mainly carried out on tissues. At present, no data has addressed this topic in the peripheral blood at a cellular level.

Objectives To investigate the activation of Th1 and Th2 cells in the peripheral blood of SSc patients.

Methods Peripheral blood mononuclear cells (PBMC) from 15 patients with SSc and 15 sex and age-matched healthy controls were investigated for intracellular IL-2, IL-4, IFN- $\gamma$. The assays were carried out on both unstimulated and PMA-activated PBMC incubated in the presence of $1 \mu \mathrm{g} / \mathrm{ml}$ of ionomycin and $10 \mu \mathrm{g} / \mathrm{ml}$ of brefeldin-A. Subsequently, samples were incubated with anti-citokines antibodies and stained cells were analysed on a FACScan flow cytometer.

Results In basal conditions (i.e. unstimulated cells), 10 out of the 15 SSc patients versus 1 out of the 15 controls presented a significantly higher percentages (i.e. $>\mathrm{m} \pm 2 \mathrm{SD}$ detected in 